\title{
Perceptions and Attitude of Students toward E-Learning in Kwara State University, Malete, Kwara State, Nigeria
}

\author{
Kennedy A. Eiriemiokhale, $\mathrm{PhD}^{1^{*}} \quad$ Victor O. Idiedo $\mathrm{PhD}^{2}$ \\ 1.Department of Library and Information Science, Kwara State University, Malete, Nigeria \\ 2.Library Department, Bayelsa Medical University, Yenagoa, Bayelsa State, Nigeria
}

\begin{abstract}
The study examined the perceptions and attitude of students toward e-learning in Kwara State University, Malete, Kwara State, Nigeria. The objectives of the study were to: examine the perceptions of undergraduates on the adoption of e-learning by Kwara State University; examine the attitude of students towards e-learning in Kwara State University, Malete; and investigate the constraints affecting e-learning by students of Kwara State University. The study adopted the survey design. The population of the study comprised the entire undergraduate students in Kwara State University, Malete. 240 students participated in the online survey. A self-designed questionnaire was used for the collection of data. Data were analysed using descriptive statistics of frequency counts and percentage. Findings of the study revealed that students have positive perceptions and attitude toward e-learning. The study also revealed the constraints affecting the use of e-learning tools by students of Kwara State University, Malete. The study recommended that the management of Kwara State University should embraced e-learning as a way of overcoming the covid-19 challenges in the university and expanding learning.
\end{abstract}

Keywords: Attitude, E-learning, Kwara State, Perceptions, Undergraduate students

DOI: $10.7176 / \mathrm{JEP} / 11-31-08$

Publication date: November $30^{\text {th }} 2020$

\section{Introduction}

In Nigeria, like many developing countries, electronic learning (e-learning) and Information Communication Technology (ICT) have become an important part of a national effort to improve education. On one hand, Nigerian educators hope that e-learning will provide a pathway to education for students whose school were closed in year 2020 due to the ravaging Covid-19 pandemic.

According to Adeoye, Adanikin and Adanikin (2020), the COVID-19 pandemic ravaging the world have taken its effects on many sectors of the economy especially in Nigeria. These effects are also evident in the Nigeria educational sector as the academic session was halted by the Federal Ministry of Education in order to curtail the spread of this virus in educational institutions. Although, this decision came as a shock to many educational institutions as many of these institutions were not prepared for the sudden disruption, others have seen it as a step in the right direction. The challenge then remains the effects of the pandemic on students and academic calendars hence, the use of e-learning as an alternative learning method.

Students learning in tertiary institutions all over the world have undergone tremendous transformation, especially since the advent of information and communication technology (ICT) (Bassey, Umoren, Akuegwu, Udida, Ntukidem \& Ekabua, 2007). There is a shift from traditional approach of teacher directed to modern methods where computer technology plays a significant role. ICT has promoted learning and made it more meaningful, where students can stay even in their homes or classrooms and receive lectures without seeing the lecturer. The aspect of ICT that has brought about this revolution in students' learning is e-learning (Bassey et al, 2007). E-learning in its broadest sense refers to any learning that is electronically enabled (Adewole-Odeshi, 2014).

The application of e-learning in developing countries has gradually advanced in recent years with an improved availability of Internet connections, local area networks, and IT support (Omidinia, Masrom, \& Selamat, 2011; Williams, Mayer, \& Minges, 2011; Rhema \& Miliszewska, 2014). However, other challenges still prevail. In developing countries, the active, participative students who are required for interactive learning are rare, and the traditional methods are widely used in teaching and learning (Evans, 2005; Andersson \& Grönlund, 2009). In addition, the developing countries often lack the ability to implement advanced educational practices on their own (Andersson \& Grönlund, 2009).

Lecturers and university management need more understanding of how students perceive and react to elements of e-learning along with how to most effectively apply an e-learning approach to enhance teaching (Park, 2009). In addition, knowing students attitude and understanding the barriers affecting the use e-learning can help academic administrators and lecturers to create mechanisms for attracting more students to adopt this learning environment (Park, 2009). Hence the need for this study.

\subsection{Objectives of the Study}

The specific objectives of this study are to:

i. examine the perceptions of undergraduates on the adoption of e-learning by Kwara State University; 
ii. examine the attitude of students towards e-learning in Kwara State University, Malete; and iii. investigate the constraints affecting e-learning by students of Kwara State University.

\subsection{Research Questions}

i. What are the perceptions of undergraduates on the adoption of e-learning by Kwara State University?

ii. What is the attitude of students towards e-learning?

iii. What are the constraints affecting e-learning by students?

\section{Review of Related Literature}

Electronic learning is learning that is not limited within the walls of a classroom, but that, which grows the prospect of using internet facilities, platforms, satellite links, and related system to access, analyse, create, exchange, and use data, information, and knowledge in ways which until recently, were almost unimaginable (Lokie, 2011). Elearning involves learning acquired through interaction with digitally delivered content, network-based services and tutoring support often with any type of on-line tool and media including the Internet, intranets, extranets, simulations and games, virtual worlds, clouds, satellite broadcasts, and web platforms (Jarmin, 2010; Pelet \& Lecarte, 2012; Schutt \& Linegar, 2013). E-learning is carried out through the use and integration of electronic medium, such as email, portal, downloadable-executable-file, social networking sites, web platforms, electronic dissertations and e-portfolios, among others (Wells, de Lange \& Fieger, 2008; Weller, 2010; Bouchard, 2011). Mobile learning which is the ability to obtain or provide educational content on personal pocket devices such as PDAs, smart phones and mobile phones, is also a form of e-learning (Kharbach, 2013).

ICT is generally believed to support cooperative learning, provide more information and, through simulation, make difficult learning experiences easier to understand. Therefore, the use of ICT cannot be overlooked either by teachers or by students. This assertion is emphasized by Van der Westhuizen (2004) who stated that, in relation to the use of ICT for learning, technology holds a promise of enhanced access to information and increased interactivity and communication between teachers and their students. Information and Communication Technology (ICT) encompasses the effective use of equipment and programmes to access, retrieve, convert, store, organize, manipulate and present data and information (Gay \& Blads, 2005). E-learning, which is described as the use of ICT to enhance or support learning and teaching in education, has become increasingly important in tertiary education (Adedeji, 2010).

For many developing countries, e-learning is considered a solution to the increasing demand for higher education. For instance, in Pakistan, online education is promoted as "education for all" as it aims to reach out to students living too far from the cities and unable to afford the cost of conventional higher education (Iqbal \& Ahmad, 2010). In Botswana, e-learning solves the problems of large classrooms, increasing enrollment, and limited staff (Ikpe, 2011). The author stated that the decision to integrate e-learning "was not borne out of a desire to join an elite club of technologically savvy universities but was out of the need to solve practical problems related to access and the quality of learning experiences". E-learning is also expected to help improve students' computer literacy (Addah, 2012). Numerous challenges were discussed with regard to promoting online education in developing countries. A survey to staff and students from three Nigerian universities revealed that the low acceptance of e-learning was due to the low awareness level, low computer literacy level, unreliable platform and Internet services, and the high cost of implementation (Folorunso, Ogunseye, \& Sharma, 2006).

E-learning is an important tool for tertiary institutions' lecturers and students (Ezenwafor \& Ementa, 2016). Ekesionye and Okolo (2011) outlined the benefits of e-learning for tertiary institutions to include enabling students to have equal access to quality education with the rest of the world, developing interesting and variety of instructional materials like lecture notes, diagrams, pictures and textbooks, entrenching lecturers and students to the global village, exposing them to international best practices in information technology, inculcating skills for on-line information sourcing for effective teaching, learning and research as well as facilitating knowledge creation and dissemination of information to a wider community. Nwokike (2011) affirmed that e-learning facilitates the task of the teacher by promoting performance, enables teachers and students to study at their own pace, reduces the stress inherent in the conventional classroom work for both teachers and students, facilitates access to existing knowledge and skills and saves teachers and learners time and energy. In agreement to the foregoing, Olojo, Adewumi and Ajisola (2012) enumerated the benefits of e-learning to tertiary institution lecturers and students to include:

i. Improving the quality of learning experiences and extends the reach of every lecturer.

ii. Helping to remove barriers to achievement by providing new and creative ways of motivating, inspiring and engaging learners of different ability levels to attain their potential.

iii. Differentiating learning to assist those with special needs the areas of literacy, numeracy and ICT.

iv. Providing a wide range of tools to enable lecturers become innovative, creative and resourceful in their activities.

v. Creating online communities of specialists, experts, practitioners, teachers, learners and interest 
(1)

groups together to share ideas and good practice.

vi. Individualizing learning to cater for all types of learners irrespective of their locations.

vii. Providing online contents to help learners locate courses of their interest and register for them.

viii. Creating a virtual learning world where learners can creatively and actively participate through simulations, role play, remote control of real world tools and devices as well as online master classes or collaboration with education providers.

Research undertaken in the area of attitude and attitude formation shows that attitudes and perceptions are interconnected, moreover, attitudes are essentially divided into likes and dislikes (Siragusa \& Dixon, 2008). University students in developing countries have varying attitudes towards e-learning but generally their attitudes are positive (El-Gamal \& El-Aziz, 2011). This was emphasised by Nassoura (2012) who revealed that many students had positive attitudes towards e-learning because it had a positive impact on their motivation as well as self-esteem.

Student attitudes towards e-learning have been identified as critical to the success of e-learning (Zhang \& Bhattacharyya, 2008). Bhuasiri, Xaymoungkhoun, Zo, Rho and Ciganek (2012) found that in developing countries the most significant factors were related to increasing technology awareness and improving attitude toward elearning, enhancing basic technology knowledge and skills, improving learning content, requiring computer training, motivating users to utilise e-learning systems, and requiring a high level of support from the university. In addition, attributes used to assess the attitudes towards ICT of students, teachers and principals have been categorised in two groups: demographics (age and gender) and computer experience (training, years of using computer, ownership of computer, access to a computer, intensity of computer use) (Jimoy-iannis \& Komis, 2007; Wen \& Shih, 2008; Papaioannou \& Charalambous, 2011).

Student levels of access to technologies represent an initial factor that would shape their attitudes towards elearning, and their willingness to use it; the availability of reliable ICTs and the convenience of accessing these technologies reflect student attitudes toward e-learning. Access to the necessary ICT infrastructure is one of the most important issues that come into focus in the assessment of how developing countries have progressed in elearning.

Despite the numerous benefits of e-learning in education, its adoption in Nigerian tertiary institutions is faced with several setbacks Ekundayo and Ekundayo (2009) identified the constraints to e-learning adoption in Nigerian tertiary institutions to include inadequate human resources, brain drain, staff-student ratio, lack of finance, poor infrastructural provision, electricity challenge, ICT and bandwidth constraints, highly bureaucratic management systems, digital divide and political instability.

The traditional means of learning, which are paper-based, are still the most commonly used in contrast to the web-based and online learning methods. According to Gulati (2008), the developing nations find the traditional means of learning more reliable and sustainable.

\section{Methodology}

This study adopted a pure quantitative method. Survey research design was adopted for the study. The design was considered suitable as recommended by Maduekwe (2011) and Uzoagulu (2011) for studies that use questionnaire to explore the opinions of a given population or its representative sample on existing phenomena. The data in this study was gathered via an online survey completed by students from seven faculties. A total of 240 students participated in the survey.

A test -re-test reliability of the questionnaire method of two weeks interval was used and responses collected were subjected to Cronbach alpha. The overall reliability of the questionnaire returned an $\mathrm{r}=0.87$ which exceed the minimum standard of 0.80 suggested for basic research (Wang and Tang, 2003). Descriptive statistics which include percentage and frequency count were used for the analysis of the data.

\section{Results}

Gender Distribution of the Respondents

Table 1: Gender

\begin{tabular}{lll}
\hline Gender & Frequency & Percentage (\%) \\
\hline Male & 113 & 47.1 \\
Female & 127 & 52.9 \\
\hline Total & 240 & 100 \\
\hline
\end{tabular}

Table 1 reveals that majority of the respondents $127(52.9 \%)$ were female students. 
Distribution of the Respondents by Age

Table 2: Age Range

\begin{tabular}{lll}
\hline Age Range & Frequency & Percentage (\%) \\
\hline $15-20$ years & 100 & 41.7 \\
$21-25$ years & 119 & 49.6 \\
$26-30$ years & 18 & 7.5 \\
31 years and above & 3 & 1.27 \\
\hline Total & 240 & 100 \\
\hline
\end{tabular}

Table 2 reveals that majority of the respondents 119(49.6\%) were between the age bracket of 21 to 25 years.

Distribution of the Respondents by Level of Study

Table 3: Level of study

\begin{tabular}{lll}
\hline Level of Study & Frequency & Percentage (\%) \\
\hline 100 level & 61 & 25.4 \\
200 level & 79 & 32.9 \\
300 level & 60 & 25 \\
400 level & 40 & 16.7 \\
\hline Total & 240 & 100 \\
\hline
\end{tabular}

Table 3 reveals that majority of the respondents 79(32.9) were 200 level students.

Research Question 1: What are the perceptions of undergraduates on the adoption of e-learning by Kwara State University?

Table 4: Perceptions about the Adoption of E-Learning by Kwara State University

\begin{tabular}{|c|c|c|c|c|c|c|c|c|c|}
\hline \multirow[t]{2}{*}{ S/No } & \multirow[t]{2}{*}{ Perception About E-Learning } & \multicolumn{2}{|c|}{ SA } & \multicolumn{2}{|c|}{$\mathbf{A}$} & \multicolumn{2}{|c|}{ D } & \multicolumn{2}{|c|}{ SD } \\
\hline & & $\mathbf{F}$ & $\%$ & $\mathbf{F}$ & $\%$ & $\mathbf{F}$ & $\%$ & $\mathbf{F}$ & $\%$ \\
\hline 1 & $\begin{array}{l}\text { E-learning offers the possibility to efficiently } \\
\text { manage my time. }\end{array}$ & 71 & 29.6 & 119 & 49.6 & 37 & 15.4 & 13 & 5.4 \\
\hline 2 & E-learning is not efficient teaching method & 54 & 22.5 & 75 & 31.2 & 99 & 41.2 & 12 & 5 \\
\hline 3 & $\begin{array}{l}\text { E-learning is a learning environment which needs } \\
\text { advanced technical knowledge to use. }\end{array}$ & 125 & 52 & 97 & 40.4 & 16 & 6.6 & 2 & 0.8 \\
\hline 4 & E-learning guarantees learning flexibility & 83 & 34.6 & 111 & 46 & 40 & 16.7 & 6 & 2.5 \\
\hline 5 & E-learning reduces students' educational cost & 47 & 19.6 & 77 & 32 & 90 & 37.5 & 26 & 10.8 \\
\hline 6 & $\begin{array}{l}\text { Students need to be trained before they undergo } \\
\text { any e-learning activity }\end{array}$ & 104 & 43 & 101 & 42 & 29 & 12 & 6 & 2.5 \\
\hline 7 & $\begin{array}{l}\text { E-learning is a waste of student's precious time } \\
\text { and energy }\end{array}$ & 29 & 12 & 35 & 14.6 & 135 & 56 & 41 & 17 \\
\hline 8 & $\begin{array}{l}\text { Students who use e-learning materials need to be } \\
\text { updated with the latest trends in technology }\end{array}$ & 134 & 55.8 & 90 & 37.5 & 14 & 5.8 & 2 & 0.8 \\
\hline 9 & E-learning is as an assisted learning tool. & 114 & 47.5 & 112 & 46.7 & 12 & 5 & 2 & 0.8 \\
\hline 10 & $\begin{array}{l}\text { Use of online learning methods makes learning } \\
\text { easier to students. }\end{array}$ & 74 & 30.8 & 93 & 38.8 & 62 & 25.8 & 11 & 4.6 \\
\hline 11 & $\begin{array}{l}\text { There is effective communication between the } \\
\text { lecturer and the students with the help of e- } \\
\text { learning }\end{array}$ & 54 & 22.5 & 72 & 30 & 93 & 38.8 & 21 & 8.8 \\
\hline 12 & Use of e-learning increases students' creativity & 76 & 31.7 & 103 & 42.9 & 51 & 21 & 10 & 4.2 \\
\hline 13 & $\begin{array}{l}\text { E-learning is seen as a self-paced learning } \\
\text { environment }\end{array}$ & 72 & 30 & 131 & 54.6 & 34 & 14.2 & 3 & 1.3 \\
\hline 14 & $\begin{array}{l}\text { The e-learning environment improves my thinking } \\
\text { skills }\end{array}$ & 74 & 30.8 & 112 & 46.7 & 45 & 18.8 & 9 & 3.8 \\
\hline 15 & $\begin{array}{l}\text { The e-learning environment enhances my } \\
\text { problem-solving skills }\end{array}$ & 47 & 19.6 & 107 & 44.6 & 74 & 30.8 & 12 & 5 \\
\hline 16 & $\begin{array}{l}\text { I like the instructor's help and suggestions in the e- } \\
\text { learning environment }\end{array}$ & 55 & 22.9 & 109 & 45.4 & 63 & 26 & 13 & 5.4 \\
\hline 17 & E-learning cannot work in Nigeria & 56 & 23 & 45 & 18.8 & 102 & 42.5 & 37 & 15.4 \\
\hline
\end{tabular}

Table 4 shows the result of analysis on students' perceptions toward e-learning. The result shows that majority of the students $119(49 \%)$ agreed that e-learning offers the possibility to efficiently manage their time, 125 (52\%) of the respondents strongly agreed that e-learning is a learning environment which needs advanced technical knowledge to use, $111(46 \%)$ of the respondents agreed that e-learning guarantees learning flexibility, 104(43\%) strongly agreed that students need to be trained before they can undergo any e-learning activity, $134(55.8 \%)$ strongly agreed that students who use e-learning materials need to be updated with the latest trends in technology, 
$114(47.5 \%)$ strongly agreed that e-learning is as an assisted learning tool, 93(38.8\%) agreed that use of online learning methods makes learning easier for students, 103(42.9\%) agreed that the use of e-learning increases students' creativity, $112(46.7 \%)$ of the respondents agreed that use of e-learning increases students' creativity, $131(54.6 \%)$ agreed that e-learning is a self-paced learning environment, $112(46.7 \%)$ agreed that e-learning environment improves their thinking skills, 107(44.6\%) agreed that e-learning environment enhances their problem-solving skills and $109(45.4 \%)$ of the respondents agreed that they like the instructor's help and suggestions in the e-learning environment

Research Question 2: What is the attitude of students towards e-learning?

Table 5: Attitude of Students towards E-Learning

\begin{tabular}{|c|c|c|c|c|c|c|c|c|c|}
\hline \multirow[t]{2}{*}{ S/No } & \multirow[t]{2}{*}{ Attitude of Students Towards E-Learning } & \multicolumn{2}{|l|}{ SA } & \multicolumn{2}{|l|}{$\mathbf{A}$} & \multicolumn{2}{|l|}{ D } & \multicolumn{2}{|l|}{ SD } \\
\hline & & $\mathbf{F}$ & $\%$ & $\mathbf{F}$ & $\%$ & $\mathbf{F}$ & $\%$ & $\mathbf{F}$ & $\%$ \\
\hline 1 & I dislike the idea of using e-learning tools & 43 & 17.9 & 56 & 23 & 117 & 48.8 & 24 & 10 \\
\hline 2 & $\begin{array}{l}\text { I have a generally favourable attitude towards using } \\
\text { e-learning tools }\end{array}$ & 57 & 23.8 & 123 & 51 & 50 & 20.8 & 10 & 4.2 \\
\hline 3 & $\begin{array}{l}\text { I believe it will be a good idea to use e-learning } \\
\text { tools }\end{array}$ & 78 & 32.5 & 106 & 44.2 & 47 & 19.6 & 10 & 4.2 \\
\hline 4 & Using e-learning tools is a foolish idea & 25 & 10.4 & 50 & 20.8 & 117 & 48.8 & 49 & 20.4 \\
\hline 5 & $\begin{array}{l}\text { If available, I intend to use e- learning tools during } \\
\text { the semester }\end{array}$ & 66 & 27.5 & 94 & 39.2 & 64 & 26.7 & 17 & 7 \\
\hline 6 & $\begin{array}{l}\text { If available, I intend to use e-learning tools as } \\
\text { frequently as possible }\end{array}$ & 59 & 24.6 & 91 & 37.9 & 77 & 32 & 14 & 5.8 \\
\hline 7 & $\begin{array}{l}\text { If available, I intend to use e-learning tools } \\
\text { whenever possible for my coursework. }\end{array}$ & 68 & 28 & 119 & 49.6 & 14 & 5.8 & 14 & 5.8 \\
\hline 8 & I feel confident in using e-learning tools & 60 & 25 & 110 & 45.8 & 55 & 22.9 & 16 & 6.7 \\
\hline 9 & I enjoy using ICT for my studies & 75 & 31.3 & 108 & 45 & 51 & 21.3 & 7 & 2.9 \\
\hline 10 & $\begin{array}{l}\text { I believe that e-learning gives me the opportunity to } \\
\text { acquire new knowledge }\end{array}$ & 84 & 35 & 111 & 46.3 & 37 & 15.4 & 9 & 3.8 \\
\hline 11 & $\begin{array}{l}\text { I believe that convenience is an important feature of } \\
\text { e-learning }\end{array}$ & 85 & 35.4 & 120 & 50 & 31 & 12.9 & 5 & 2.1 \\
\hline 12 & $\begin{array}{l}\text { E-learning increases the quality of learning because } \\
\text { it integrates all forms of media }\end{array}$ & 75 & 31.3 & 127 & 52.9 & 31 & 12.9 & 8 & 3.3 \\
\hline 13 & $\begin{array}{l}\text { I would be interested in studying courses that use e- } \\
\text { learning }\end{array}$ & 52 & 21.7 & 121 & 50.4 & 53 & 22 & 15 & 6.3 \\
\hline 14 & $\begin{array}{l}\text { Adopting ICT and e-learning allows for increased } \\
\text { student satisfaction }\end{array}$ & 58 & 24.2 & 115 & 47.9 & 53 & 22 & 15 & 6.3 \\
\hline 15 & I will never participate in e-learning & 24 & 10 & 38 & 15.8 & 120 & 50 & 59 & 24.6 \\
\hline
\end{tabular}

Table 5 shows the result of analysis on students' attitude towards e-learning. Majority of the respondents $123(51 \%)$ agreed that they have generally favourable attitude towards using e-learning tools, 106(44.2\%) agreed that it will be a good idea to use e-learning tools, 94(39.2\%) agreed that if available, they intend to use e- learning tools during the semester, 119(49.6\%) agreed that if available, they intend to use e-learning tools whenever possible for their coursework, $110(45.8 \%)$ agreed that they feel confident in using e-learning tools, $108(45 \%)$ of the respondents agreed that they enjoy using ICT for their studies, 111(46.3\%) agreed that e-learning gives them the opportunity to acquire new knowledge, $120(50 \%)$ of the respondents agreed that convenience is an important feature of e-learning, 127(52.9\%) agreed that E-learning increases the quality of learning because it integrates all forms of media, and $115(47.9 \%$ ) agreed that adopting ICT and e-learning allows for increased student satisfaction. Research Question 3: What are the constraints affecting e-learning by students? 
Table 6: Constraints Affecting E-Learning by Students of Kwara State University

\begin{tabular}{|c|c|c|c|c|c|c|c|c|c|}
\hline \multirow[t]{2}{*}{ S/No } & \multirow{2}{*}{$\begin{array}{l}\text { Constraints Affecting E-Learning by Students of } \\
\text { Kwara State University }\end{array}$} & \multicolumn{2}{|l|}{ SA } & \multicolumn{2}{|l|}{$\mathbf{A}$} & \multicolumn{2}{|l|}{ D } & \multicolumn{2}{|l|}{ SD } \\
\hline & & $\mathbf{F}$ & $\%$ & $\mathbf{F}$ & $\%$ & $\mathbf{F}$ & $\%$ & $\mathbf{F}$ & $\%$ \\
\hline 1 & Lack computer literacy skills & 108 & 45 & 103 & 42.9 & 24 & 10 & 5 & 2.1 \\
\hline 2 & Lack of internet skills & 91 & 37.9 & 112 & 46.7 & 30 & 12.5 & 7 & 2.9 \\
\hline 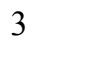 & $\begin{array}{l}\text { Ignorance of ways of utilizing e-learning for } \\
\text { receiving lectures }\end{array}$ & 82 & 34.2 & 128 & 53.3 & 28 & 11.7 & 2 & 0.8 \\
\hline 4 & Lack of interest in learning new skills & 69 & 28.8 & 109 & 45.4 & 55 & 22.9 & 7 & 2.9 \\
\hline J & le use of & 88 & 36.7 & 123 & 51.3 & 26 & 10.8 & 3 & 1.3 \\
\hline 6 & or utilizis & 63 & 26.3 & 125 & 52 & 48 & 20 & 4 & 1.7 \\
\hline 7 & conte & 95 & 39.6 & 111 & 46.3 & 32 & 13.3 & 2 & 0.8 \\
\hline 8 & fits of e-1 & 68 & 28.3 & 114 & 47.5 & 51 & 21.3 & 7 & 2.9 \\
\hline 9 & mputer & 70 & 29.2 & 118 & 49.2 & 43 & 17.9 & 9 & 3.8 \\
\hline 10 & to take online co & 85 & 35.4 & 96 & 40 & 53 & 22 & 6 & 2.5 \\
\hline 11 & art phor & 78 & 32.5 & 99 & 41.3 & 51 & 21.3 & 12 & 5 \\
\hline 12 & subscribe to data & 116 & 48.3 & 88 & 36.7 & 29 & 12 & 7 & 2.9 \\
\hline 13 & Constant power failure & 134 & 55.8 & 87 & 36.3 & 17 & 7 & 2 & 0.8 \\
\hline
\end{tabular}

Table 6 shows the result of analysis on constraints affecting e-learning by Kwara State university students. Majority of the respondents 108(45\%) strongly agreed to lack computer literacy skills, 112(46.7\%) agreed to lack of internet skills, 128(53.3\%) agreed to ignorance of ways of utilizing e-learning for receiving lectures, 109(45.4\%) agreed to lack of interest in learning new skills, 123(51.3\%) agreed to lack of training on the use of e-learning tools, 125(52\%) agreed to lack of confidence for utilizing e-learning, 111(46.3\%) agreed to inability to understand contents delivered online, $114(47.5 \%)$ agreed to ignorance of the benefits of e-learning, $118(49.2 \%)$ agreed to inability to procure computer, $96(40 \%)$ agreed to lack of skills to take online continuous assessment, 99(41.3\%) agreed to inability to procure smart phones, $116(48.3 \%)$ strongly agreed to inability to subscribe to data, and $134(55.8 \%)$ agreed to constant power failure.

\subsection{Discussion of Findings}

The findings of this study have revealed that students have positive perceptions towards e-learning. They believe that e-learning help them to efficiently manage their time, that e-learning guarantees learning flexibility, that students who use e-learning materials need to be updated with the latest trends in technology, that e-learning is as an assisted learning tool, that use of online learning methods makes learning easier for students and that e-learning increases students' creativity. The results also disagreed with the perception that e-learning is a waste of students' time and the perception that e-learning cannot work in Nigeria. This finding agrees with that of Akpan and Tralagba (2019) which reported that students are favorably disposed to the adoption of mobile technologies for learning and that undergraduates also showed their willingness to procure their own mobile technology devices if they are introduced for learning. This finding is also in alignment with that of Ihechukwu and Chima (2016) which revealed that students have positive perceptions towards use of e-learning in science education.

The study also revealed the attitude of students toward e-learning. The results revealed positive attitude of students towards e-learning. They have generally favourable attitude towards using e-learning tools and they agreed that they will use e-learning tools if made available. This finding is in agreement with that of AdewoleOdeshi (2014) which reported that students have a positive attitude towards e-learning because they find the system easy to use and useful for their course work. This finding is also emphasised by that of Nassoura (2012) which pointed out that many students had positive attitudes towards e-learning because it had a positive impact on their motivation as well as self-esteem.

The study further identified the constraints affecting the use of e-learning tools by students. These constrains include lack computer literacy skills, lack of internet skills, ignorance of ways of utilizing e-learning for receiving lectures, lack of interest in learning new skills, lack of training on the use of e-learning tools, lack of confidence for utilizing e-learning, inability to understand contents delivered online, ignorance of the benefits of e-learning, inability to procure computer, lack of skills to take online continuous assessment, inability to procure smart phones, inability to subscribe to data, and constant power failure. This finding is supported by that of Ezenwafor and Ementa (2016) which reported that despite the numerous benefits of e-learning in education, its adoption in Nigerian tertiary institutions is faced with several setbacks. The finding is also buttressed by that of Ekundayo and Ekundayo (2009) which outlined the constraints to e-learning adoption in Nigerian tertiary institutions to include inadequate human resources, brain drain, staff-student ratio, lack of finance, poor infrastructural provision, electricity challenge, ICT and bandwidth constraints, highly bureaucratic management systems, digital divide and political instability. 


\section{Conclusion}

The study examined the perceptions and attitude of students toward e-learning in Kwara State University, Malete, Nigeria. The findings of the study have far reaching implications for e-learning in tertiary institutions in Nigeria. The COVID-19 pandemic is making the educational sector to look inward. Institutions are now embracing elearning which serves as alternative to the face-to-face contact learning thereby helping the institutions cover gaps the pandemic have on the institutions academic calendar. The study revealed that though the students have positive attitude towards e-learning, e-learning in Nigeria is bedeviled with numerous challenges.

\subsection{Recommendations}

Based on the findings of the study, the following recommendations are made:

i. The Federal Government of Nigeria through the Ministry of Education should mandate the National University Commission to urgently develop an e-learning policy for Nigerian universities.

ii. The management of Kwara State University should embraced e-learning as a way of overcoming the covid-19 challenges in the university.

iii. E-learning tools should be made available in schools by the three tiers of government

\section{References}

Addah, J. (2012). Computer literacy and E-learning: Attitudes among first year students in a Ghanaian medical school. International Journal of Computer Applications, 51, 22.

Adedeji OA (2010). The development of modern information and communications technology in Ibadan: Creative Educational Publications Ltd. p. 58.

Adewole-Odeshi, E. (2014). Attitude of students towards e-learning in South-West Nigerian universities: An application of Technology Acceptance Model. Library Philosophy and Practice. Retrieved from https://digitalcommons.unl.edu/libphilprac/1035.

Adeoye, I. A., Adanikin, A. F. \& Adanikin, A. (2020). COVID-19 and e-learning: Nigeria tertiary education system experience. International Journal of Research and Innovation in Applied Science, v(v), 28-31. Retrieved from http//:www.rsisinternational.org.

Akpan, A. G. \& Tralagba, C. E. (2019). Perception of mobile phone users on e-learning in Evangel University, Akaeze-Nigeria. Global Science Journal, 7(7). 325-344.

Andersson, A., \& Grönlund, A. (2009). A conceptual framework for E-learning in developing countries: A critical review of research challenges. The Electronic Journal on Information Systems in Developing Countries, 38(2), $1-16$.

Bassey, U. Umoren, G. Akuegwu, B. Udida, L. Ntukidem, P \& Ekabua, O. (2007). Nigerian graduating students' access to E-learning technology: Implication for higher education management. Proceedings of the 6th International internet Education conference,(ICTlearn2007) held in Cairo Egypt from 2-4 September 2007, pp59-76.

Bhuasiri, W., Xaymoungkhoun, O., Zo, H., Rho, J, J., \& Ciganek, A, P. (2012). Critical success factors for elearning in developing countries: A comparative analysis between ICT experts and faculty. Computers \& Education, 58 (1), 843-855.

Bouchard, P. (2011). Network promises and their implications. In The Impact of Social Networks on Teaching and Learning [online monograph]. Revistade Universidad y Sociedad del Conocimiento, 8(1), 288-302.

Ekesionye, N. E. \& Okolo, A. N. (2011). Optimizing e-learning opportunities: An effective and necessary tool towards branding higher education in Nigerian Society. In N. Onyegegbu, \& U. Eze (Eds), Optimizing elearning Opportunities for Effective Education Service Delivery. University of Nigeria Nsukka: Institute of Education.

Ekundayo, M. S. \& Ekundayo, J. M. (2009). Capacity constraints in developing countries: A need for more elearning space? The case of Nigeria. Proceeding of Ascilite Auckland, 243-255.

El Gamal, S., \& Abd El Aziz, R. (2011) „An Investigation of the Effect of Higher Education Students' Perception on their Readiness for E-Learning Adoption', The 2011 International Conference on e-Learning, e-Business, Enterprise Information Systems, and e-Government, WORLDCOMP'11, EEE'11: July 18-21, 2011, USA.

Evans, R. (2005). Explaining low learner participation during interactive television instruction in a devel-oping country context. PhD Thesis, University of Pretoria, Pretoria. Retrieved from http://upetd.up.ac.za/thesis/submitted/etd-02282005-081708/unrestricted/00front.pdf.

Ezenwafor, J. I. \& Ementa, C. N. (2016). Assessment of constraining factors to e-learning adoption by business educators in tertiary institutions in Anambra State. International Journal of Innovative Education Research 4 (2), 22-31. Retrieved from http://seahijap.org.

Folorunso, O., Ogunseye, O. S., \& Sharma, S. K. (2006). An exploratory study of the critical factors affecting the acceptability of e-learning in Nigerian universities. Information Management \& Computer Security, 14(5), 496-505. 
Gay G, Blads R (2005). Information Technology for CXC CSEC. Oxford University Press, UK.

Gulati, S. (2008). Technology-enhanced learning in developing nations: A review. International Review of Research in Open and Distance Learning, 9(1), 1-16.

Ihechukwu, N. B. Ikwuanusi, E. N. \& Chima, U. (2016). Students' perceptions of use of e-learning in science education. JORIND 14(1), 1-7. Retrieved from http://www.transcampus.org/journal.

Ikpe, I. B. (2011). E-learning platforms and humanities education: An African Case Study. International Journal of Humanities and Arts Computing, 5(1), 83-101.

Iqbal, M. J., \& Ahmad, M. (2010). Enhancing quality of education through e-learning: The case study of Allama Iqbal Open University. Turkish Online Journal of Distance Education, 11, 84-97.

Jimoyiannis, A., \& Komis, V. (2007). Examining teachers' beliefs about ICT in education: Implications of a teacher preparation programme. Teacher Development, 11(2), 149-173.

Kharbach, M. (2013). 14 technology concepts every teacher should know about. Retrieved from http:/www.educators technology. co./2013/03/14/14 technology concepts every teacher should know about.

Lokie, J. M. (2011). Examining student achievement and motivation using internet-based inquiry in the classroom. Open Access Theses and Dissertations from the College of Education and Human Sciences. Paper 102. Retrieved from http://digitalcommons. unl.edu/cehsdiss/102.

Nassoura, A. B. (2012). Students' acceptance of mobile learning for higher education in Saudi Arabia. American Academic \& Scholarly Research Journal, 4(2). Retrieved from http://aasrc.org/aasrj/index.php/aasrj/article/download/248/188.

Nwokike, F. O. (2011). Optimizing e-learning for effective delivery of business education in tertiary institutions in the 21 st century. In N. Onyegegbu, \& U. Eze (Eds), Optimizing e-learning opportunities for effective education service delivery. University of Nigeria Nsukka: Institute of Education.

Olojo, O. J.; Adewumi, M. G.; Ajisola, K. T. (2012). E-learning and its effects on teaching and learning in a global age. International Journal of Academic Research in Business and Social Sciences, 2(1), 203-209.

Omidinia, S., Masrom, M., \& Selamat, H. (2011). Review of e-learning and ICT infrastructure in develop-ing countries (Case study of Iran). American Journal of Economics and Business Administration, 3(1), 120-125. Retrieved from http://thescipub.com/pdf/10.3844/ajebasp.2011.120.125.

Papaioannou, P., \& Charalambous, K. (2011). Principals' attitudes towards ICT and their perceptions about the factors that facilitate or inhibit ICT integration in primary schools of Cyprus. Journal of Informa-tion Technology Education, 10, 349-369. Retrieved from http://www.jite.org/documents/Vol10/JITEv10p349369Papaioannou958.pdf.

Park, S. (2009). How are universities involved in blended instruction? Educational Technology \& Society, 12(3), $327-342$

Pelet, J. E \& Lecat, B. (2013) Virtual worlds as the next asset of virtual learning environments for students in business? International Journal of Virtual and Personal Learning Environments, 3(2), 59-76

Rhema, A., \& Miliszewska, I. (2012). The potential of e-learning in assisting post-crisis countries in re-building their higher education systems: The case of Libya. Issues in Informing Science and Informa-tion Technology, 9, 149-160. Retrieved from http://iisit.org/Vol9/IISITv9p149-160Rhema033.pdf.

Schutt, S \& Linegar, D. (2013). We learn as we go: What five years playing with virtual worlds has taught us. International Journal of Virtual and Personal Learning Environments, 4(2), 124-136.

Siragusa, L., \& Dixon, K. (2008). Planned behaviour: Student attitudes towards the use of ICT interactions in higher education. In Hello! Where are you in the landscape of educational technology? Proceedings ascilite Melbourne 2008. Retrieved from http://www.swaraunib.com/indra/Sistem\%20informasi/TPB/siragusa.pdf. 